\title{
Exchange rate volatility and oil prices shocks and its impact on economic sustainability
}

\author{
Khuram Shafi ${ }^{\mathrm{a}, \mathrm{b}^{*}}$, Liu Hua ${ }^{\mathrm{c}}$ and Zahra Idrees ${ }^{\mathrm{a}}$
}

${ }^{a}$ PhD Scholar, School of Management, Hua Zhong University of Science and Technology, Wuhan, China

${ }^{b}$ Assistant professor, COMSATS Institute of Information Technology, Pakistan

${ }^{c}$ Professor, School of Management, HuaZhong University of Science and Technology, Wuhan, China

\section{CH RON I C L E A B S T R A C T}

Article history:

Received September 18, 2014

Accepted 10 December 2014

Available online

December 152014

Exchange rate volatility

Gross domestic product

Co integration

\begin{abstract}
Impact of exchange rate volatility has received a great attention from the last century, its importance is certain in all sectors of the economy and it affects welfare as well as social life of the economy. Exchange rate between two currencies tells the value of one currency in terms of others one. Depreciation/Appreciation of exchange rate affects economic growth in terms of trade and shifts income to/from exporting countries from/to importing countries. The factors affecting exchange rate are inflation, interest rate, foreign direct investment, government consumption expenditure and balance of trade. This research study examines the impact of oil prices and exchange rate volatility on economic growth in Germany based on 40-year annual data. Cointegration technique is applied to check the impact of macroeconomic variables on exchange rate in the long run and short run. It is estimated that imports, exports, inflation, interest rate, government consumption expenditure and foreign direct investment had significant impacts on real effective exchange rate in the long run and short run. Sin addition, Engle Granger results indicate that relationship was significant for the long run and its error correction adjustment mechanism (ECM) in short a run is significant and correctly signed for Germany.
\end{abstract}

\section{Introduction}

Gross domestic product is one of the important barometers to measure the economic growth. Exchange rate volatility and fluctuation in oil prices adversely influence on economic growth. This problem is faced by both developing and developed countries. The various factors affecting exchange rate are inflation, interest rate, exports, imports, foreign debt, industrial growth and foreign direct investment. Exchange rate and oil prices have a significant impact on the growth of the economy. So, the research problem is to find out the macroeconomic variables like imports, exports, inflation, interest rate, government consumption expenditure and foreign direct investment have a significant impact on exchange rate. Exchange rate volatility and oil prices fluctuations have significant long run relationships with economic growth. The aim of this study is to check the long run as well as short run

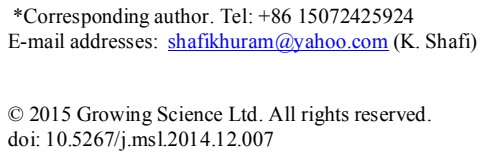


impact of exchange rate and oil prices on economic growth, and to identify macroeconomic variables that are affected by exchange rate such as inflation, export, import, interest rate, foreign direct investment, government consumption expenditure and what are those factors which control volatility in the exchange rate.

\section{Literature review}

Oil prices and appreciation in exchange rate are positively correlated with gross domestic product (GDP). A rise in oil prices has affected the global economy positively. The rise in oil prices is due to increase in demand not by supply side effects. Oil prices are more worthwhile than monetary contraction. Federal Reserve's in case of increase in oil prices may increase interest rate to control inflation. Increase in oil prices is affecting the oil producing countries in two contexts. First is positive effect that is income and wealth increases in oil producing countries, because importing countries pay more and if the exporting countries utilize income in their home countries then more investment will be in countries and this increases employment in the society. It increases money supply in the society and currency appreciates in this regard. Second effect is negative because increase in oil prices will decrease demand for oil in oil importing countries and worsens balance of trade position in oil exporting country (Al-Ezzee, 2011; Aliyu, 2009; Amano \& Van Norden, 1998; Brahim Fezzani, 2011; Bjørnland, 2009; Hamilton, 2009; Kilian, 2007; Jiménez-Rodríguez \& Sanchez, 2005).

Any changes in the real exchange rates would lead to fluctuations in short term capital flows. It plays an important role in economic activities; therefore the real exchange rate has been one of the most debated issues both in theory and the practice. The effect of real exchange rate on economic growth has been examined, and it has been found that there was a negative relationship between the two variables. Devaluation of a currency leads contraction in aggregate demand and output. Devaluation increases general price level and decreases in real money value increases demand for nominal money and interest rate and has a negative impact on investment and consumption decisions. Government has to pay more money for external debt, which is either generated from taxes or reduces expenditure. If it is by increase in taxes then it will reduce the private sector spending and negatively will affect economy (Choudhary \& Chaudhry, 2007). Literature empirically proves that depreciation in exchange rate will make imports expensive and it will encourage exports and stronger balance of trade position and will lead to higher economic growth. Despite that, appreciation in exchange rate will make imports cheap and has studied affect the economic growth as well (Aliyu, 2009; Tille, 2003; Hsing, 2005; Al-Ezzee, 2011).

If government increases its spending it will increase consumption, decrease balance of trade and depreciation in exchange rate and have a positive impact on GDP (Kim, 2007). Foreign direct investment is regarded as an important source of capital financing (Globerman \& Shapiro, 1999). Government implement different strategies to foster economic growth and regime stability leading to increase in foreign direct investment inward (Ravn, 2012). If foreign direct investment is used in nontradable sector, it will lead to appreciation of the currency (Jaffri \& Ahmed, 2010). Different countries have proposed various causes of inflation. Either it is due to the supply of money or due to increase in import prices that causes depreciation of the currency (Ahmad \& Ali, 1999). Empirical analysis showed that a rise in oil prices in Russia has a positive impact on economic growth and appreciation in rubble will lead to increase in GDP in long run and no impact in short run. Japan is unable to produce oil for its domestic consumption and rely on importing oil from other countries, which creates a negative relationship between oil and GDP. Any appreciation in Japanese yen is associated with fall in GDP in long run as well as in short run. No long run relationship is found in china because it may be oil importing and exporting country and pegging of Yuan with US dollar virtually (Jin, 2008). GDP of Russia is increasing due to high oil production and relatively high oil prices, producing 10 million barrel oil per day and exports of 7.3 million barrel oil per day. Russian currency, rubble, is linked with US dollar and European euro. Appreciation of Russian rubble is positively correlated with economic growth in long run and has no significant impact in short run. Demand for oil is increasing day by day 
and depends upon demand and supply of oil, its consumption and alternatives availability of resources. It is analyzed that increase in oil prices is negatively correlated with economic growth for oil importing country (Aliyu, 2009; Jin, 2008). Germany a largest industrial economy is 5th largest consumer of oil in all over the world. Unable to meet its domestic demand for oil and is the fourth largest importer of oil in 2006 . Germany can only produce $2.57 \%$ of total consumption of oil domestically and imported 2.48 million barrel oil per day in 2006. An increase in oil prices are negatively correlated with economic growth (Hsing, 2011). Japan which is the second largest economy imports oil for its domestic consumption. It is the second largest oil importer and third largest oil consumer in all over the world. Rise in oil prices and appreciation of currency is not a good sign for Japan (Jin, 2008). Accordingly, empirical studies have explored different point of views or finding about the relationship nature between economic growth, exchange rate, and oil price fluctuations.

\section{Methodology}

Growth of any country is affected by different macroeconomic variables like government investment and consumption decisions, foreign direct investment, industrial and manufacturing growth rate, oil prices and exchange rate. Oil prices and exchange rate affect positively as well as negatively to the different countries. Annual data of variable is taken from International Financial Statistics (IFS) from 1971 to 2012. GDP is taken in national currency in billions. Data of exchange rate variability is taken as CPI based real effective exchange rate from the same source. Data of world oil prices is taken in current US \$. Then conversion of all the data in US dollar.

$$
\mathrm{GDP}=\alpha+\beta_{1} \Delta \mathrm{ROIL}+\beta_{2} \mathrm{REXR}+\mu
$$

Based on the model of Jin (2008) and Aliyu (2009), co integration technique is applied for the analysis. Where all the results are estimated on E-views 7 statistical package and cointegration technique is applied for the analysis.

REER is real effective exchange rate, which is also checked as an endogenous variable with certain macroeconomic variables. Exchange rate of a country is affected by inflation. Annual data of imports, exports and government consumption expenditure is taken in local currency in billions from 1971 to 2012. Data of foreign direct investment and Consumer price index (2005) is taken from International financial statistics (IFS) in rate. First of all impact of inflation, interest rate, Government consumption expenditure, imports and exports of a country on exchange rate is to be seen by using cointegration technique. The results of cointegration analysis show that there was a long run relationship between variables and exchange rate of Germany.

$$
\mathrm{REXR}=\beta_{0}+\beta_{1} \mathrm{EXP}+\beta_{2} \mathrm{IMP}+\beta_{3} \mathrm{IR}+\beta_{4} \mathrm{FDI}+\beta_{5} \mathrm{GC}+\mu
$$

Before applying any statistical technique Stationarity of the time series data is to be checked. ADF augmented ducky fuller is a most trustworthy source for checking the Stationarity of the data.

\section{Results}

First, augmented dickey-fuller (ADF) test is applied. Result shows that there was a long run relationship among the variables at the first difference as shown in Table 1.

\section{Table 1}

The results of ADF Test

\begin{tabular}{lccccc}
\hline \multicolumn{1}{c}{ Variables } & Test Specification & ADF Test & Critical Value & Prb & DW \\
\hline GDP & IT $-\Delta-1 \%$ & -6.02 & -4.219 & 0.0001 & 1.98 \\
OILP & IT $-\Delta-1 \%$ & -8.3 & -4.219 & 0.0000 & 2.02 \\
ReeR & I- $\Delta-1 \%$ & -5.77 & -3.62 & 0.0000 & 1.99 \\
\hline
\end{tabular}


Table 3 presents the results of short run adjustment mechanism error correction mechanism. Optimal lag selection is tested and it fulfills all the criteria at lag 1 as shown in Table 2. All the series are found to be integrated at the same order. All the variables are significant at first difference, in such case I (1) exist and equilibrium relationship exists among the variables. The two-step Engle and Granger model suggests that if any set of co integrated time series has an error-correction representation, which reflects the short-run adjustment mechanism. The lag value of the residual term must be negative showing that shocks in the long run having short run adjustment mechanism. ECM is general to specific approach to econometric modeling.

Table 2

The results of Lag selection

\begin{tabular}{ccccccc}
\hline Lag & Log L & LR & FPE & AIC & SC & HQ \\
\hline 0 & -86.24564 & NA & 0.019509 & 4.576699 & 4.704666 & 4.62261 \\
1 & 46.39704 & $238.0766^{*}$ & $3.45 \mathrm{e}-05^{*}$ & $-1.763951^{*}$ & $-1.25208^{*}$ & $-1.58028^{*}$ \\
\hline
\end{tabular}

Table 3

The results of cointegration and Error Correction Mechanism

\begin{tabular}{ccccc}
\hline Variables & Coeff. & S.E & t-stat & Prob. \\
\hline C & -0.0104 & 0.0027 & -3.8386 & 0.0005 \\
D(REER) & 0.0002 & 0.0007 & 0.3264 & 0.7461 \\
D(OILP) & 0.0003 & 0.0003 & 1.0180 & 0.3157 \\
UT(-1) & -0.0469 & 0.0250 & -1.8772 & 0.0688 \\
\hline
\end{tabular}

A fundamental parameter in the estimation of the short-run dynamic model is the coefficient of errorcorrection term, which measures the speed of adjustment of real GDP to its equilibrium level. The results show that the factor of the error-correction terms in the model was statistically significant and correctly signed. This confirms that GDP has automatic adjustment mechanism and that the economy responds to deviations from equilibrium in balancing manner for Germany. As far as t-statistics are concerned if t-statistics are statistically significant then the shocks will adjust in that year and the remaining will be carry forward to the next year and if t-statistics are insignificant then the shock will recover in the same year. So the econometric equation will be;

$$
\text { GDP }=-0.0104-0.0469 \text { Ut }(-1)+0.0002 \text { REER }+0.0003 \text { OILP }
$$

From the above results, the signs of real effective exchange rate and oil prices both are positive showing that 1 unit increase in exchange rate will cause 0.0002 units change in GDP and 1 unit increase in oil prices will cause 0.0003 units change in GDP. To check either cointegration exist in consumer price index ( CPI), export( EXP), government expenditure (GCE), imports (IMP), interest rate (IR), foreign direct investment (FDI) with endogenity of real effective Exchange rate (REER), which shows stochastic trend that can only be removed by taking first difference. Unit root test is applied to check the Stationary of the data at level and first difference. A technique for Stationary of data is Augmented dickey fuller a most trustworthy source.

Table 4

The results of ADF test

\begin{tabular}{cllllll}
\hline Variable & & Test Specificion & ADF Test & Critic-al Value & Prb & DW \\
\hline ER & IT- $\Delta-1 \%$ & -5.39 & -4.219 & 0.0004 & 1.91 \\
CPI & IT- $\Delta-1 \%$ & -6.08 & -4.22 & 0.0001 & 2.02 \\
EXPR & IT- $\Delta-1 \%$ & -4.49 & -4.226 & 0.0051 & 1.93 \\
GCE & IT- $\Delta-1 \%$ & -4.16 & -3.616 & 0.0023 & 1.66 \\
IMP & IT $-\Delta-1 \%$ & -5.17 & -4.23 & 0.0005 & 2.05 \\
IR & IT- $\Delta-1 \%$ & -6.21 & -4.227 & 0 & 2 \\
FDI & IT- $-1 \%$ & -4.58 & -3.61 & 0.0007 & 2.08 \\
\hline
\end{tabular}


All the variables are integrated at first difference so order of integration is 1 . After the estimation of order of cointegration, lag order must be selected. As long as we wish to achieve this purpose, VAR lag order selection criteria must be used. For this purpose we use: Final Prediction Error (FPE), Akaike Information Criterion (AIC), Schwarz Information Criterion (SIC), and Hannan-Quinn Information Criterion (HQ). Table 5 shows the results of the optimal lag Selection. According to the results lag 1 is to be selected for in the VAR model.

Table 5

The results of optimal Lag selection Criteria

\begin{tabular}{ccccccc}
\hline Lag & $\log \mathrm{L}$ & LR & FPE & AIC & SC & HQ \\
\hline 0 & -628.33 & NA & 5403910 & 32.5298 & 32.7858 & 32.6217 \\
1 & -485.41 & $234.5462^{*}$ & $22988.21^{*}$ & $27.04641^{*}$ & $28.83794^{*}$ & $27.68920^{*}$ \\
\hline
\end{tabular}

The value of Trace statistics and maximum Eigen value will tell the number of cointegration equations in this. It is noted that Trace statistics is greater than critical value at 5\% level of significance and there exists some cointegration (long run relationship) among the variables. From the results of Table 6 as per trace statistics there are 3 cointegration equations.

Table 6

The results of unrestricted cointegration Rank Test

\begin{tabular}{ccccc}
\hline No. of CE $(\mathrm{s})$ & Eigenvalue & Trace Statistic & 0.05 Critical Value & Prob.** \\
\hline None & 0.669662 & 145.8702 & 125.6154 & 0.0016 \\
At most $1 *$ & 0.590822 & 103.7799 & 95.75366 & 0.0125 \\
At most 2 & 0.548760 & 69.82296 & 69.81889 & 0.0500 \\
At most 3 & 0.403091 & 39.58420 & 47.85613 & 0.2377 \\
At most 4 & 0.259870 & 19.97653 & 29.79707 & 0.4244 \\
At most 5 & 0.199766 & 8.541231 & 15.49471 & 0.4095 \\
At most 6 & 0.001916 & 0.072868 & 3.841466 & 0.7872 \\
\hline
\end{tabular}

REER=28.75-3.613expr+11.967imp-1.047inf+9.143IR-6.964FDI+1.763GCE

$$
\begin{array}{llllll}
3.12 & -4.25 & 4.14 & 4.32 & 5.98 & -0.88
\end{array}
$$

Eq. (4) indicates that in Germany 1 unit increase in exports will cause decrease in real effective exchange rate by 3.613 units and 1 unit increase in imports will cause 11.96 unit increases in real effective exchange rate and interest rate and government consumption expenditure are positively correlated. And 1 unit increase foreign direct investment and inflation will cause 1.047 and 6.96 units decrease in real effective exchange rate, respectively.

\section{Conclusion}

The results of this study have indicated that exchange rates and oil prices had positive relation with GDP of the Germany. Positive sign has indicated that any rise in oil prices would be affecting positively to GDP and in exchange rate would also increase in GDP. Short run error adjustment mechanism shows that all the errors exist in short run. In addition, the effect of imports, exports, interest rate, inflation, government consumption expenditure and foreign direct investment could influence on exchange rate. Interest rate, government consumption and import of the country had significant effect and positively associated with the exchange rate while the exports, inflation and foreign direct investment had negatively associated with the real effective exchange rate. 


\section{References}

Al-Ezzee, D. I. (2011). Real Influences of Real Exchange Rate and Oil Price Changes on The Growth of Real GDP: Case of Bahrain. International Conference on Management and Service Science, 8, 155-164.

Ahmad, E., \& Ali, S. A. (1999). Relationship between Exchange Rate and Inflation. Pakistan Economic and Social Review, 37(2), 139-154.

Aliyu, S. U. R. (2009). Impact of Oil Price Shock and Exchange Rate Volatility on Economic Growth in Nigeria: An Empirical Investigation. Research Journal of International Studies (11), 4-15.

Amano, R. A., \& Van Norden, S. (1998). Oil prices and the rise and fall of the US real exchange rate. Journal of international Money and finance, 17(2), 299-316.

Bjørnland, H. C. (2009). Oil price shocks and stock market booms in an oil exporting country. Scottish Journal of Political Economy, 56(2), 232-254.

Brahim Fezzani, D. N. (2011). Oil Prices Fluctuation Impact on Iraq's Economy. European Journal of Social Sciences, 26(4), 626-633.

Globerman, S., \& Shapiro, D. M. (1999). The Impact of Government Policies on Foreign Direct Investment: The Canadian Experience. Journal of International Business Studies, 30(3), 513-532.

Jaffri, A. A., \& Ahmed, I. (2010). Impact of Foreign Direct Investment (FDI) Inflows on Equilibrium Real Exchange Rate of Pakistan. South Asian Studies, 25(1), 125-141.

Hamilton, J. D. (2009). Causes and Consequences of the Oil Shock of 2007-08: National Bureau of Economic Research.

Hsing, Y. (2005). Impact of Monetary Policy, Fiscal Policy, and Currency Depreciation on Output: The Case of Venezuela. Briefing Notes in Economics (65), 1-9.

Hsing, Y. (2011). Impacts of Higher Crude Oil Prices and Changing Macroeconomic Conditions on Output Growth in Germany. Journal of European Union Economics and Finance (2), 60-66.

Jiménez-Rodríguez, R., \& Sanchez, M. (2005). Oil price shocks and real GDP growth: empirical evidence for some OECD countries. Applied economics, 37(2), 201-228.

Jin, G. (2008). The Impact of Oil Price Shock and Exchange Rate Volatility onEconomic Growth: A Comparative Analysis for Russia Japan and China. Research Journal of Internatıonal Studies (8), 98-111.

Kilian, L. (2007). Not all oil prices are alike:Disentangling demand and supply shocks in the oil market forthcoming in American Economic review.

Kim, J. (2007). Real exchange rates and real interest differentials for sectoral data: A dynamic SUR approach. Economic letters 97, 247-252.

Choudhary, M. A., \& Chaudhry, M. A. (2007). Effects of the exchange rate on output and price level: evidence from the Pakistani economy. Lahore Journal of Economics, 12(1), 49-77.

Ravn, M. O. S.-G., Stephanie Uribe, Martín. (2012). Consumption, government spending, and the real exchange rate. Journal of Monetary Economics, 59(3), 215-234. doi: 10.1016/j.jmoneco.2012.02.001

Tille, C. (2003). The Impact of Exchange Rate Movements on U.S. Foreign Debt. Current Issues in Economics and Finance, 9(1), 1-7. 